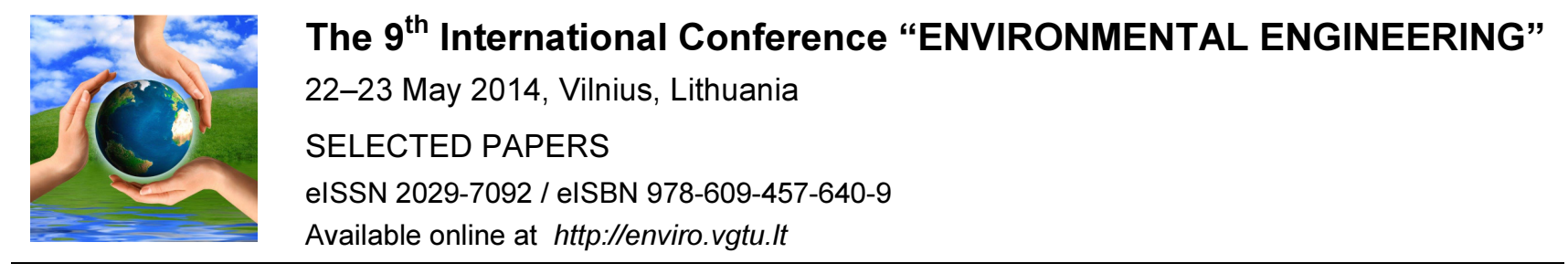

Section: Technologies of Geodesy and Cadastre

\title{
Subdivision as a tool for regulating and approving legal status of real estate
}

\author{
Agnieszka Bieda, Paweł Hanus \\ AGH University of Science and Technology, 30 Mickiewicza av., 30-059 Krakow, Poland
}

\begin{abstract}
Subdivision surveying of land property, in its basic form, is a technical and administrative procedure which can be called one of the most important elements of the real estate management. Its purpose is to separate at least two new cadastral parcels, without changing their current owner. The preparation of a proper real estate subdivision plan should serve the purpose of appropriate use of investment opportunities which are associated with it. However, under the Polish law, there are numerous premises to perform subdivisions, whose sole purpose will be to form a new structure of land ownership or to approve the existing legal status. The paper is aimed at systematizing the most important, according to the Authors, surveying and legal procedures creating new boundaries, separating the existing real estate or the one which is to be created by virtue of law.

Subdivisions approving the existing legal status of real estate are performed when it is necessary to transfer ownership rights to only part of a real property. Normally, it happens when a fragment of a plot is used by the so-called autonomous possessor, as if it was their own. Such a person can apply before a common court to be conferred ownership rights to the land, which they use. That land must, however, be subdivided as a separate cadastral parcel.

A similar situation occurs when a parcel adjacent to land under flowing surface water will be permanently taken away by this water. Automatically, if the water exceeds the cadastral boundaries, part of the parcel flooded by the river becomes the property of the owner of the water. In Poland, it is the State Treasury. Subdividing this part of land covered by water is conducted in the process of determining the course of a boundary line. A similar situation occurs when a public road was built on a private property. By virtue of law, the owner of the road is entitled to the ownership rights to part of the real estate seized for that road. The subdivisions in order to parcel out land for a road are subject to separate regulations.

The subdivisions can also regulate the legal status of real estate. It is possible in such cases where on part of the real estate, which is private property, public investments are planned, i.e. actions of strategic importance for the functioning of a society. Depending on the nature of such investment, subdivision procedure will be conducted differently, and the result will always be the transfer of ownership rights to a separate cadastral parcel. Deprivation of ownership rights to the separated part of the real estate is held under an administrative decision in the course of expropriation proceedings. The most distinctive, however, are the subdivisions performed under the Special Roads Acts, most frequently in order to separate a lane of local and supralocal significance. The subdivisions for railroads, airports, pipelines, flood protection structures or nuclear power facilities are conducted in a similar manner.
\end{abstract}

Keywords: approve; legal status of real estate; real estate subdivisions; regulate.

\section{Real estate subdivisions}

Subdivision surveying of land property is one of the most important real estate management processes. Its purpose is to change the configuration of cadastral parcels in the area. As a result of the real estate subdivision, new objects of the cadastre are separated from a cadastral parcel [1], [20]. A consequence of a typical subdivision, however, can not be changes to the rights attributed to the real property. The subdivision, however, is often necessary to determine the range of changes to the legal status.

Corresponding author: Paweł Hanus. E-mail address: pawel.hanus@agh.edu.pl http://dx.doi.org/10.3846/enviro.2014.190

(C) 2014 The Authors. Published by VGTU Press. This is an open-access article distributed under the terms of the Creative Commons Attribution License, which permits unrestricted use, distribution, and reproduction in any medium, provided the original author and source are credited. 
Subdivisions of real estate in Poland are performed by surveyors with the professional license marked as " 2 " b , i.e. qualified for delimitation and subdivision of real estate (land) and for the preparation of documentation for legal purposes [17]. Methods of performing real estate subdivisions are determined by the applicable laws. The type of the standards depends on the purpose for which the subdivision is performed and what kind of real estate is subject to subdivision. The procedures described by law have been summarized in Table 1 .

Table 1. Real estate subdivisions in the Polish law

\begin{tabular}{|c|c|c|c|}
\hline Legal basis & Type of real estate & Purpose & Conditions to be met by subdivision \\
\hline \multirow[t]{4}{*}{ The Real Estate Management Act [9] } & \multirow[t]{3}{*}{$\begin{array}{l}\text { Developed real estate or } \\
\text { planned for development }\end{array}$} & Any & $\begin{array}{l}\text { Compatible with the existing spatial } \\
\text { planning documents }\end{array}$ \\
\hline & & To enlarge the adjacent real estate & $\begin{array}{l}\text { Regardless of the settlements of spatial } \\
\text { planning documents if they do not } \\
\text { prohibit the subdivision for the purpose } \\
\text { of enlarging the adjacent real estate }\end{array}$ \\
\hline & & Exceptions from Article 95 & $\begin{array}{l}\text { Regardless of the settlements of spatial } \\
\text { planning documents for the purpose } \\
\text { specified in the Act }\end{array}$ \\
\hline & Agricultural land & $\begin{array}{l}\text { To enlarge the adjacent real estate, } \\
\text { in order to regulate the boundaries, } \\
\text { to parcel out new public roads }\end{array}$ & $\begin{array}{l}\text { Regardless of the settlements of spatial } \\
\text { planning documents, plots of land } \\
\text { smaller than } 0.3000 \text { ha are created }\end{array}$ \\
\hline $\begin{array}{l}\text { The Geodetic and Cartographic Law } \\
\text { [17] }\end{array}$ & Agricultural land & Any & $\begin{array}{l}\text { Plots of land larger than } 0.3000 \text { ha are } \\
\text { established }\end{array}$ \\
\hline The Civil Code [11] & All & $\begin{array}{l}\text { Dissolution of co-ownership } \\
\text { acquisitive prescription of part of a } \\
\text { property, division of the inheritance }\end{array}$ & Lack \\
\hline The Water Law [18] & All & Determination of the shoreline & $\begin{array}{l}\text { Separated parts of a plot taken by } \\
\text { flowing water }\end{array}$ \\
\hline $\begin{array}{l}\text { The provisions introducing the acts } \\
\text { reforming public administration [19] }\end{array}$ & All & Regulation of legal status of roads & $\begin{array}{l}\text { Separated parts of a plot seized for a } \\
\text { public road }\end{array}$ \\
\hline $\begin{array}{l}\text { The Act on special rules for the } \\
\text { preparation and implementation of } \\
\text { the investments in public roads [13] }\end{array}$ & All & Construction of a public road & Lack \\
\hline The Act on rail transport [16] & All & Construction of a railway line & Lack \\
\hline $\begin{array}{l}\text { The Act on special rules for the } \\
\text { preparation for the implementation of } \\
\text { the investments in flood protection } \\
\text { structures [15] }\end{array}$ & All & $\begin{array}{l}\text { Construction of flood protection } \\
\text { structures }\end{array}$ & Lack \\
\hline $\begin{array}{l}\text { The Act on the preparation and } \\
\text { implementation of the investments in } \\
\text { nuclear power facilities and } \\
\text { associated investments [12] }\end{array}$ & All & $\begin{array}{l}\text { Construction of nuclear power } \\
\text { facilities and ancillary facilities }\end{array}$ & Lack \\
\hline $\begin{array}{l}\text { The Act on special rules for the } \\
\text { preparation and implementation of } \\
\text { the investments in airports for public } \\
\text { use [14] }\end{array}$ & All & $\begin{array}{l}\text { Construction of facilities related to } \\
\text { airports for public use }\end{array}$ & Lack \\
\hline $\begin{array}{l}\text { The Act on the investments related to } \\
\text { a re-gasification terminal for liquefied } \\
\text { natural gas in Swinoujscie [10] }\end{array}$ & All & $\begin{array}{l}\text { Construction of facilities related to } \\
\text { the LNG terminal }\end{array}$ & Lack \\
\hline
\end{tabular}

While completing Table 1, it should be mentioned what is contained in article 95 of the Act on Real Estate Management [9]. It contains exceptions when the subdivision of real estate can be conducted, in accordance with the procedure written in the Act, however, these subdivisions shall not be in any way dependent upon the settlements in the planning documents. These situations include:

- dissolution of co-ownership of real estate developed with at least two buildings, erected on the basis of a building permit, if the subdivision is to divide the buildings and plots of land among the individual co-owners, as indicated in the joint application, necessary for the proper use of these buildings,

- subdividing of a building plot, if the building was erected on this plot by an autonomous possessor in good faith,

- subdividing of part of the real estate, the ownership or perpetual usufruct of which has been acquired by virtue of law,

b In Poland, there are seven areas of professional licenses in surveying and cartography. All are awarded to persons meeting the imposed statutory criteria, i.e. adequate education, professional practice and passed state examination [17] 
- execution of the claims to part of the real estate, under the provisions of the Act on Real Estate Management, or other acts,

- enforcement of the regulations on ownership transformation or liquidation of state-owned or local government enterprises,

- subdividing of part of the real estate covered by the decision to determine the location of a public road,

- subdividing of part of the real estate covered by the decision to determine the location of a railway line,

- subdividing of part of the real estate covered by the decision to authorize the investment in airports for public use,

- subdividing of part of the real estate covered by the decision to authorize the investment in flood protection structures,

- subdividing of a building plot required for the use of a residential building,

- subdividing of plots of land in closed areas ${ }^{c}$.

Most of the subdivisions listed in Table 1 do not affect the rights to real estate, but relate only to the configuration of boundaries - changing only the land information. However, there are those as well, whose approval will result in changes to the legal status of the subdivided real estate (clause 3), and those that will approve such a change (clause 2). Regardless of the conducted subdivision procedure, its surveying part and technical documentation prepared during almost all subdivision procedures, is the same [4].

A surveyor has no possibility to perform the real estate subdivision without notification of this work to the District ${ }^{\mathrm{d}}$ Cartographic Information Center ${ }^{\mathrm{e}}$ [17]. The notification must be submitted to the Center which is locally competent, relative to the location of real estate. It is important that it was submitted before the planned commencement of the work [6]. The Center is obliged to acknowledge the receipt of the notification and record it immediately, no later than on the following day. Within 10 working days of the notification of the surveying works, a surveyor should receive a written response to it, which will include guidelines for the implementation of the subdivision of the property and a list of materials from the National Cartographic Resource ${ }^{\mathrm{f}}$, which should be used to perform the declared work. The confirmed notification is also a document authorizing a surveyor to examine the legal status of the real estate. It also allows to access to the premises and to carry out the necessary field work.

Then the surveyor moves on to the activities authorized by the notification, i.e. collecting the materials from the Center, examining the legal status of the real estate, surveying inspection and a measurement. An analysis of the collected materials allows a surveyor to properly prepare for the next necessary steps - the approval of real estate boundaries subject to the subdivision [7].

The activities regarding the approval of real estate boundaries shall be notified to the owner or perpetual usufructuary of the real estate subject to subdivision, as well as to the owners or usufructuaries of the real estate adjacent to the one subject to subdivision, and in the absence of data about these people - to the persons managing that real estate. The notices are served on the parties, with return receipt requested, no later than 7 days before the set date of approving the boundaries [17].

The real estate subdivision plan is prepared in accordance with the real estate boundaries accepted in the field. Field work is the basis for the completion of the survey report, which must be included in the National Cartographic Resource, so that the subdivision was performed successfully. The survey report includes [8]:

- field sketches and field measurement book,

- protocol from the acceptance of the subdivided real estate boundaries,

- proofs of service of notices regarding the activities related to the approval of the boundaries of the subdivided real estate,

- technical report,

- documents containing the results of measurement, including topographic descriptions of control points,

- data files generated from the so-called operating database, stored on computer media in accordance with the relevant GML application schemas,

- other documents (or their certified copies) obtained and used by the surveyor,

- a list of the documents of the survey report.

The most important elements are the protocol from the acceptance of the subdivided real estate boundaries and the map of the division project. The protocol includes [7]:

- designation of the real estate subject to the subdivision, according to the data of the real estate cadastre and land register, and in the absence thereof - according to other documents defining the legal status of the real estate,

- information on the documents forming the basis for accepting the boundaries of the real estate subject to the subdivision,

- sketch of the boundary course of the real estate subject to the subdivision,

- description of the boundary course and location of the boundary points of the real estate subject to the subdivision,

- date when the protocol was drawn up, the name, number of the professional license and the signature of the person who prepared the protocol.

\footnotetext{
${ }^{c}$ Closed areas - areas of restricted access due to national defense and security of the country, defined by the relevant ministers and heads of central offices [17].

d District - a unit of administrative division in Poland

e National Cartographic Information Center - an administrative and surveying office, whose task is to supervise and control the content and quality of surveying works and including them into the resource.

f National Cartographic Resource - a collection of maps and photogrammetric materials, remote sensing materials, records, lists, information databases, survey data catalogues and other studies produced as a result of surveying and mapping works[17].
} 
The map on the other hand [7]:

- location of the real estate subject to the subdivision,

- address of the real estate subject to the subdivision,

- map scale,

- the boundaries of the real estate subject to the subdivision,

- designation of the real estate subject to the subdivision, according to the data from the cadastre and land register, and in the absence thereof - according to other documents defining the legal status of this real estate,

- designation of the neighbouring real estates according to the data from the cadastre,

- area of the real estate subject to the subdivision and the areas of the plots of land designed to be subdivided, outlined in red,

- outlined in red, boundaries of the plots of land designed to be subdivided,

- outlined in red, designations of the plots of land designed to be subdivided,

- overview sketch in a scale enabling to locate the real estate subject to the subdivision,

- a list of changes in land records,

- a synchronization list, in the case when in the land register, or in the absence thereof, in other documents defining the legal status of the real estate, this real estate subject to the subdivision has other designations and other area than in the real estate cadastre,

- site development elements, necessary for the real estate subdivision project, and in particular: fences, buildings, landscape architecture, wells, septic tanks, connections, trees which are natural monuments, elements of public utilities running through the real estate subject to the subdivision,

- date when the map was prepared, the name, number of the professional license and the signature of the person who prepared the map.

Acceptance of the survey report to the Center is made at the request of the surveyor. In the Center, the report is controlled in technical and formal terms. Within 6 working days as of the submitted application, a Supervisor employed at the Center with the professional license "2" shall carry out the control procedure [6].

\section{Subdivisions approving the legal status of real estate}

The subdivisions approving the legal status should be understood as those which do not affect the rights to the property in any way, and whose task is to determine the range of the existing legal status. Such a need will always occur when an authorized entity acquired ownership or perpetual usufruct to part of real estate by virtue of law. In order to be able to unambiguously identify this piece of real estate to which the acquired right is assigned, it must be designated. Designation of the real estate will include the determination of its location, boundaries and area. The procedure which makes it possible is subdivision of real estate.

\subsection{Acquisitive prescription to part of a parcel of land}

Acquisitive prescription [11] of a parcel of land is one of the ways to acquire certain rights in rem to a real estate (ownership rights, transmission easement ${ }^{g}$, land easement ${ }^{\mathrm{h}}$ and, unless it was previously established, perpetual usufruct ${ }^{\mathrm{i}}$ ). The aim of the acquisitive prescription procedure is to update the legal status of a real estate according to the factual circumstances (ownership status). The statement of prescription takes place in non-litigious judicial proceedings. The basis of acquisitive prescription is uninterrupted autonomous possession of real estate and passage of time.

Autonomous possession is understood as the actual possession of a real estate, with the intention of having it for themselves, without a legal title (land register, administrative decision or judgment of the court conferring a right to the property, notarial deed transferring the right to real estate, etc.). If an autonomous possessor is not aware of the fact that the real estate used is not really theirs, it might become subject to acquisitive possession after 20 years (i.e. in good faith). If they are aware of the fact that that they do not own the real estate or that they did not exercise due diligence in checking whether the real estate was validly acquired, the time extends to 30 years (i.e. in bad faith). This time is counted as of the moment of taking autonomous possession of the real estate and it can not be interrupted. The good or bad faith of the autonomous possessor is determined on the date of taking up real estate in possession.

The result of an acquisitive prescription is acquiring rights to the real estate. It occurs by virtue of law, so upon the lapse of the period required for the prescription, the former owner loses their right to the real estate. The court's decision does not create a new legal status of the property, but only approves the factual circumstances.

\footnotetext{
$\mathrm{g}$ Transmission easement - a limited right in rem, according to which the owner of the facilities which are used for providing or drainage of fluids, vapours, gas, electricity and other similar devices can use, within a given range, the real estate on which these facilities were built. The scope of using the real estate results from the use of the facilities [11].

${ }^{\mathrm{h}}$ Land easement - a limited right in rem, encumbering real estate in order to increase the utility of another real property called the dominant tenement. Mostly created to provide access to a real property which does not have an access to a public road [11].

i Perpetual usufruct - a legal right on a land property owned by the State Treasury or local government units of letting it in use to a natural or legal person for a specified period from 40 to 99 years [11]
} 
Prescription may cover the whole of, or part of, a land property. In the case of acquisitive prescription of part thereof, a consequence is subdivision of the real estate in order to parcel out a new real estate with the new owner. Such subdivision is performed upon a court order conducting the prescription and approved with its decision. The same decision approves the transfer of the ownership right upon the autonomous possessor.

The Real Estate Management Act [9] allows for the already mentioned subdividing of a building plot, if the building was erected by the autonomous possessor in good faith, as well as for subdividing part of the real estate, the ownership or perpetual usufruct of which have been acquired by virtue of law (here: prescription based on [11]). This means that subdividing of part of the real estate which is subject to acquisitive prescription is carried out as described in [9]. The subdivision, however, will not be approved by an administrative decision as most subdivisions in [9], but by the judgment of a court, which, as already mentioned, also transfers ownership rights to separate part of the real estate.

\subsection{Determining the course of a shoreline}

Under the Polish Water Law [18], the territorial sea waters, internal sea waters, inland flowing surface waters and groundwaters are the property of the State Treasury, and the land covered by surface waters are the property of the owner of these waters and are part of the real property of the State Treasury [9]. Land covered by surface waters and internal sea waters is land forming the bottoms and banks of natural water courses, lakes and other natural bodies, within the boundaries of the shoreline. In addition, if the flowing surface waters or the territorial sea waters or internal waters occupy permanently, in a natural way, the land which is not a property of the water owner, this land then becomes the property of the water owner.

From these regulation it is evident that when a meandering river or wavy sea invades the land, it takes, by virtue of law, private property adhering to the lands covered by the waters.

It is easily imaginable that, due to the variable nature of water, those cases are not rare, and that is why they have received their own surveying and administrative procedure - delimitation of the land covered by water from the adjacent land, a procedure of determining the course of the shoreline. It really has little to do with real estate delimitation [2]. Its effect is the separation of part of the property occupied by water. The subdivision line usually coincides with the shoreline, which is:

- the clearly defined edge of the shore,

- if the edge of the shore is not clearly defined - it is boundary of permanent grass growth,

- if the boundary of the permanent grass growth lies above the average water level for a period of at least the last 10 years, it is the line of intersection of water surface at this level with the adjacent land,

- if the shores of the water are regulated - the shoreline shall run along the outer edges of the regulatory structures, and at the willow plantations on the land acquired as a result of the regulation - along the boundary of the plantation from the land side.

By way of decision, at the request of an entity having a legal or factual interest, the shoreline is determined by:

- the appropriate maritime authority - for internal sea waters,

- competent province marshal ${ }^{\mathrm{j}}$ - for boundary waters and inland waterways,

- competent starost ${ }^{\mathrm{k}}$ executing a task of the government administration - for other waters.

The basis for determining the shoreline is a project of delimitation of the land covered by waters from the adjacent land, supplied by the applicant, which includes, among others:

- the adopted method for determining the course of a shoreline,

- determination of the legal status of real estates covered by the project, with their owners identified,

- status of water relations on the land adjacent to the proposed shoreline,

- the as-built map of regulatory structures or an updated copy of the base map showing: national control points, boundary of permanent grass growth, edges of shores, alluviums, river bars and islands, as well as the proposed shoreline.

Due to significant differences between the above-described procedure and the surveying subdivision of real estate, a diagram of determining the course of a shoreline, after [5], has been presented in Table 2.

A decision establishing a shoreline does not approve changes in the legal status of the real estate. Land occupied by the flowing waters, by virtue of law, become the property of the State Treasury. Nevertheless, the land covered by surface flowing waters is included in the real estate stock of the State Treasury by way of an administrative decision of a locally competent starost performing a government administrative task [18].

\footnotetext{
${ }^{j}$ Province Marshal - the chairman of the government of the province, i.e. the largest unit of administrative division in Poland.

${ }^{\mathrm{k}}$ Starost - the chairman of the district self-government, i.e. a medium unit of administrative division in Poland.
} 
Table 2. Determining the course of a shore line

\begin{tabular}{|c|c|c|c|}
\hline $\begin{array}{l}\text { Stages of the process of determining the } \\
\text { course of a shoreline }\end{array}$ & Surveying part & Hydrological part & Administrative part \\
\hline \multirow[t]{2}{*}{$\begin{array}{l}\text { preparation of materials for a project of } \\
\text { delimitation of land covered by waters } \\
\text { form adjacent land }\end{array}$} & - & $\begin{array}{l}\text { determining a scope of information } \\
\text { necessary for as-built surveys or } \\
\text { updating the base map }\end{array}$ & - \\
\hline & $\begin{array}{l}\text { as-built surveys or updating the base } \\
\text { map, determining boundaries of the } \\
\text { real estate included in the project }\end{array}$ & - & - \\
\hline \multirow{4}{*}{$\begin{array}{l}\text { preparing a project of delimitation of } \\
\text { land covered by waters form adjacent } \\
\text { land }\end{array}$} & & project of the course of a shoreline & \\
\hline & - & & - \\
\hline & survey of the course of a shoreline & - & - \\
\hline & $\begin{array}{l}\text { preparing a mapping part of the } \\
\text { project of delimitation of land covered } \\
\text { by waters form adjacent land }\end{array}$ & $\begin{array}{l}\text { preparing a descriptive part of the } \\
\text { project of delimitation of land covered } \\
\text { by waters form adjacent land }\end{array}$ & - \\
\hline $\begin{array}{l}\text { issuance of an administrative decision } \\
\text { determining a shoreline }\end{array}$ & - & - & $\begin{array}{l}\text { issuance of an } \\
\text { administrative decision } \\
\text { determining a shoreline }\end{array}$ \\
\hline
\end{tabular}

\subsection{Subdivisions for regulating the legal status of existing public roads}

According to the introductory provisions of the Act reforming public administration [19], the real estate remaining on December 31, 1998 in the possession of the State Treasury or local government units, which did not constitute their property, and occupied by public roads, on January 1, 1999, by virtue of law, they became property of the State Treasury or the relevant local government units. The basis for the acquisition of ownership rights to real estate is the final decision of the governor ${ }^{1}$. Such a decision does not establish a new legal status. It is only a confirmation of the factual circumstances as of December 31, 1998. In order for this decision to be issued, three conditions must be met [3]:

- possession of the real estate on 31.12 .1998 by the State Treasury or local government unit,

- on 31.12.1998, the owner was some other entity than the Treasury or the local government unit,

- the real estate was seized for a public road before 31.12.1998.

These provisions do not apply to real estates which in due time were in perpetual usufruct. The roads constructed on real estates acquired by the State Treasury or local government units, also had to be assigned to one of the categories of public roads (in 1998 these included: national, provincial, municipal and local urban in corporate areas). It was, of course, verified by relevant documents:

- Resolution of the Council of Ministers for national roads,

- Regulation of the Minister of Communications and Administration and Spatial Planning for provincial roads,

- Resolution of the provincial national council (after 1990 - the municipal council) for municipal roads and local urban roads,

- Resolution of the provincial national council for roads in corporate areas.

The real estate was taken over only in so far as it was actually used as a road. Therefore, it may turn out to be necessary to separate this part of the real estate by surveying. If required, the surveying subdivision is approved by way of a governor's decision, who shall decide on the transfer of the ownership rights.

\section{Subdivisions regulating the legal status of real estate}

In contrast to performing real estate subdivisions aimed to designate part thereof having the legal status altered in various processes, there are subdivisions which are part of the process of creating a new legal status of real estate. In the described cases, the legal status shall be changed only after the real estate subdivision procedure.

\subsection{Expropriated part of real estate}

Expropriation of real estate is the deprivation or limitation, by decision, of ownership rights, right of perpetual usufruct or other rights in rem to an immovable property, in the case when these rights can not be acquired by agreement [9]. Expropriation is performed only for the State Treasury or local government units. Expropriation proceedings for the 
Treasury are initiated ex officio, and for a local government unit - upon request. It should be preceded by negotiations for the acquisition of ownership rights by agreement.

The authority competent in expropriation matters is the starost, performing a government administrative task. Expropriated can only be this real property, which is located in areas designated for public purposes in the relevant planning documents, and only if these objectives can not be achieved in other ways. The main public purposes are:

- subdividing land for public roads,

- construction and maintenance of public facilities for water supply and sewage disposal,

- construction and maintenance of the environment protection facilities,

- protection of real property which constitutes cultural heritage,

- construction and maintenance of facilities for the purpose of national defense and security,

- construction of cemeteries,

- construction and maintenance of buildings for government offices, courts, universities and other public institutions,

- exploration of minerals belonging to the State Treasury and others.

The entire property or part thereof may be covered by expropriation. In the event of expropriating part of a real estate, the application shall be accompanied by a map with a subdivision project and a decision approving the subdivision. The subdivision shall be performed on the basis of relevant planning documents, which contain a description of the public purpose implemented on the expropriated land. It is worth highlighting, that at the time of the expropriation, the real estate subdivision has already been approved by a decision issued by a commune head, a mayor or the president of a city ${ }^{\mathrm{m}}$. Starost's expropriation decision relates only to a change in ownership rights to subdivided part of the real property, and not the process of subdividing itself.

\subsection{Subdivisions under the "Special Purpose Acts"}

"Special Purpose Acts" is a common name for a group of laws that have been created in order to improve the preparation and implementation of investments in specific areas. Some of them significantly affect the methodology of subdivision of the real estate designated for public purposes. The most important "Special Purpose Acts" include the following:

- Special Road Act - the Act on special rules for the preparation and implementation of the investments in public roads [13],

- Special Railroad Act - the Act on railway transport [16],

- Special Airport Act - the Act on special rules for the preparation and implementation of the investments in airports for public use [14],

- Special Act on LNG Terminal - the Act on the investments related to a re-gasification terminal for liquefied natural gas in Swinoujscie [10],

- Special Act on Flood Control - the Act on special rules for the preparation for the implementation of the investments in flood protection structures [15],

- Special Nuclear Power Act - the Act on the preparation and implementation of the investments in nuclear power facilities and associated investments [12].

The model of proceedings in all of these "Special Purpose Acts" is always similar. An authorized entity submits an application to the authority issuing the decision, which will allow to implement the investment. If it is required by the planned construction, the application shall be accompanied by maps with a subdivision project. The maps shall be prepared in accordance with separate regulations - [7], [8], [9].

A decision authorizing the implementation of an investment includes, in particular, lines demarcating the investment area and the approval of the real property subdivision. Demarcation lines become the new boundaries of the real estate. The final decision transfers ownership rights to the real property or part thereof upon the new owners. The description of administrative procedures leading to the subdivision of real estate under a "Special Purpose Act" has been contained in Table 3.

The Real Estate Management Act [9] was enacted in 1997, before all the "Special Purpose Acts" [10], [12], [13], [14], [15] and [16]. Article 95, which was mentioned earlier (Table 1), could, in the subdivision of real estate, successfully replace them all. An administrative decision approving the implementation of an investment, issued as a Special Purpose Act, in addition to the approval of subdivisions, is also a decision allowing for:

- location of an investment,

- transfer of ownership rights,

- commencement of a construction. 
Table 3. Specification of the "Special Purpose Acts"

\begin{tabular}{|c|c|c|c|c|}
\hline „Special Purpose Act” & Decision & Applicant & Issuing authority & New owner of real estate \\
\hline Road & $\begin{array}{l}\text { allowing for the implementation } \\
\text { of a road investment }\end{array}$ & road manager & $\begin{array}{l}\text { governor (national } \\
\text { and provincial roads) } \\
\text { starost (other roads) }\end{array}$ & $\begin{array}{l}\text { State Treasury or } \\
\text { appropriate local } \\
\text { government unit }\end{array}$ \\
\hline Railway & $\begin{array}{l}\text { determining the location of a } \\
\text { railway line }\end{array}$ & PKP Polish Railway Lines S.A. & governor & State Treasury \\
\hline Airport & $\begin{array}{l}\text { allowing for the implementation } \\
\text { of an investment in airports for } \\
\text { public use }\end{array}$ & $\begin{array}{l}\text { entity establishing the airport, } \\
\text { airport manager or Polish Air } \\
\text { Navigation Services Agency }\end{array}$ & governor & $\begin{array}{l}\text { State Treasury or } \\
\text { appropriate local } \\
\text { government unit }\end{array}$ \\
\hline LNG Terminal & $\begin{array}{l}\text { determining the location of the } \\
\text { LNG terminal }\end{array}$ & investor mentioned in the Act & governor & State Treasury \\
\hline Flood Control & $\begin{array}{l}\text { allowing for the implementation } \\
\text { of an investment }\end{array}$ & investor & governor & $\begin{array}{l}\text { State Treasury or } \\
\text { appropriate local } \\
\text { government unit }\end{array}$ \\
\hline Nuclear & $\begin{array}{l}\text { determining the location of an } \\
\text { investment in the construction of } \\
\text { a nuclear power facility }\end{array}$ & $\begin{array}{l}\text { investor meeting the conditions } \\
\text { of the Act }\end{array}$ & governor & State Treasury \\
\hline
\end{tabular}

\section{Summary}

Summarizing the paper, the authors would like to emphasize that:

- each real estate subdivision consists of a surveying procedure and an administrative procedure, which often does not have the slightest effect on the legal status of the real property being subdivided;

- the main surveying and legal works approving the existing legal status are the subdivisions performed for the purpose of acquisitive prescription, delimitation of the land covered by water from the adjacent land, as well as the regulation of the legal status of the land under public roads;

- the subdivisions which are elements regulating the legal status, other than those described in the work, the subdivision for the purpose of expropriation of part of real estate, or the subdivisions under the "Special Purpose Acts", can also include those performed for the dissolution of co-ownership or division of the inheritance.

All of the analyzed cases of subdivisions which affect the ownership structure have been presented in Table 4 .

Table 4. Subdivisions regulating and approving the legal status of real property

\begin{tabular}{|c|c|c|c|}
\hline Type of subdivision & $\begin{array}{l}\text { Document approving the } \\
\text { subdivision project }\end{array}$ & $\begin{array}{l}\text { Authority approving } \\
\text { the subdivision project }\end{array}$ & Notes \\
\hline Adverse possession of part of real estate & Final court decision & Common court & $\begin{array}{l}\text { This confirms the acquisition of } \\
\text { ownership rights or perpetual } \\
\text { usufruct by virtue of law }\end{array}$ \\
\hline Determining the course of a shore line & Final administrative decision & Starost & $\begin{array}{l}\text { This confirms the acquisition of } \\
\text { ownership rights by virtue of law }\end{array}$ \\
\hline $\begin{array}{l}\text { Subdivisions in order to regulate the legal status of } \\
\text { existing public roads }\end{array}$ & Final administrative decision & Governor & $\begin{array}{l}\text { This confirms the acquisition of } \\
\text { ownership rights by virtue of law }\end{array}$ \\
\hline Expropriation of part of real estate & Final administrative decision & Starost & Transfers ownership rights \\
\hline $\begin{array}{l}\text { Subdivisions for the implementation of a public } \\
\text { investment under "Special Purpose Acts" }\end{array}$ & Final administrative decision & Governor or Starost & Transfers ownership rights \\
\hline
\end{tabular}

\section{Acknowledgements}

This work is financed from the funds for science, no 11.11.150.006, realized at AGH University of Science and Technology, Faculty of Mining Surveying and Environmental Engineering, Department of Geomatics, allocated for the year 2014.

\section{References}

[1] Bojar, Z. 2012. Podziaty nieruchomości. Komentarz. Katowice: Wydawnictwo GALL. ISBN: 978-83-60968-27-7. Language: Polish, English: Subdivisions of real property. Commentary.

[2] Durzyńska, M. 2009. Rozgraniczenie i podziat nieruchomości. Warszawa: Wydawnictwo Prawnicze LexisNexi. Language: Polish, English: Delimitation and subdivision of real property.

[3] Gdesz, M.; Trembecka, A. 2011. Regulowanie stanu prawnego nieruchomości pod drogi. Katowice: Wydawnictwo GALL. ISBN: 978-83-60968-147. Language: Polish, English: Regulating legal status of real estate intended for public roads 
[4] Hycner, R.; Hanus, P. 2007. Wykonawstwo geodezyjne. Katowice: Wydawnictwo GALL. ISBN 978-83-60968-01-7. Language: Polish, English: Geodetic execution

[5] Kowalski, K. 2010. Gospodarka nieruchomościami pokrytymi powierzchniowymi wodami plynacymi, Wrocław: E-book, Language: Polish, English: Real estate management of lands covered by surface flowing waters

[6] Rozporządzenie Ministra Rozwoju Regionalnego i Budownictwa z dnia 16 lipca 2001 r. w sprawie zgłaszania prac geodezyjnych i kartograficznych, ewidencjonowania systemów i przechowywania kopii zabezpieczajacych bazy danych, a także ogólnych warunków umów o udostępnianie tych baz (Dz. U. Nr 78, poz. 837). Language: Polish, English: Regulation of the Minister of Regional Development and Construction of 16 July 2001 on the notification of surveying and mapping works, system records and storage of backup safety database copies, as well as the general terms of the agreements on making databases available (Journal of Laws No. 78, item 837).

[7] Rozporządzenie Rady Ministrów z dnia 7 grudnia 2004 r. w sprawie sposobu i trybu dokonywania podziatów nieruchomości (Dz. U. Nr 268, poz. 2663). Language: Polish, English: Regulation of the Council of Ministers of 7 December 2004 on the procedures for performing subdivisions of real estate (Journal of Laws No. 268, item 2663).

[8] Rozporządzenie Ministra Spraw Wewnętrznych i Administracji z dnia 9 listopada 2011 r. w sprawie standardów technicznych wykonywania geodezyjnych pomiarów sytuacyjnych $i$ wysokościowych oraz opracowywania i przekazywania wyników tych pomiarów do państwowego zasobu geodezyjnego i kartograficznego (Dz. U. Nr 263, poz. 1572). Language: Polish, English: Regulation of the Minister of Internal Affairs and Administration of 9 November 2011 on the technical standards for the performance of horizontal and height measurements, and the preparation and transfer of these measurements results to the National Cartographic Resource (Journal of Laws No. 263, item 1,572)

[9] Ustawa z dnia 21 sierpnia 1997 r. o gospodarce nieruchomościami (Dz. U. Nr 115 poz. 741, z póz. zm.) Language: Polish, English: The Real Estate Management Act of 21 August 1997 (Journal of Laws No. 115, item 741, as amended).

[10] Ustawa z dnia 24 kwietnia 2009 r. o inwestycjach w zakresie terminalu regazyfikacyjnego skroplonego gazu ziemnego w Świnoujściu (Dz. U Nr 84, poz. 700, z póz. zm.). Language: Polish, English: The Act of 24 April 2009 on investments in re-gasification terminal for liquefied natural gas in Swinoujscie (Journal of Laws No. 84, item 700, as amended).

[11] Ustawa z dnia 23 kwietnia 1964 r. - Kodeks cywilny (Dz. U. Nr 16, poz. 93, z póz. zm.). Language: Polish, English: The Act of 23 April 1964 - the Civil Code (Journal of Laws No. 16, item 93, as amended),

[12] Ustawa z dnia 29 czerwca 2011 r. o przygotowaniu i realizacji inwestycji $w$ zakresie obiektów energetyki jądrowej oraz inwestycji towarzyszacych (Dz. U Nr 135, poz. 789, z póz. zm.). Language: Polish, English: The Act of 29 June 2011 on the preparation and implementation of the investments in nuclear power facilities and associated investments (Journal of Laws No. 135, item 789, as amended).

[13] Ustawa z dnia 10 kwietnia 2003 r. o szczególnych zasadach przygotowania i realizacji inwestycji w zakresie dróg publicznych (Dz. U. Nr 80, poz. 721, z póz. zm.). Language: Polish, English: The Act of 10 April 2003 on special rules for the preparation and implementation of the investments in public roads (Journal of Laws No. 80, item 721, as amended).

[14] Ustawa z dnia 12 lutego 2009 r. o szczególnych zasadach przygotowywania i realizacji inwestycji w zakresie lotnisk użtku publicznego (Dz. U. Nr 42, poz. 340, z póz. zm.). Language: Polish, English: The Act of 12 February 2009 on special rules for the preparation and implementation of the investments in airports for public use (Journal of Laws No. 42, item 340, as amended).

[15] Ustawa z dnia 8 lipca 2010 r. o szczególnych zasadach przygotowania inwestycji w zakresie budowli przeciwpowodziowych (Dz. U. Nr 143, poz. 963, z póz. zm.). Language: Polish, English: The Act of 8 July 2010 on special rules for the preparation of investment in flood protection structures (Journal of Laws No. 143, item 963, as amended).

[16] Ustawa z dnia 28 marca 2003 r. o transporcie kolejowym (Dz. U. Nr 16, poz. 94, z póz. zm.). Language: Polish, English: The Act of 28 March 2003 on railway transport (Journal of Laws No. 16, item 94, as amended)

[17] Ustawa z dnia 17 maja 1989 roku - Prawo geodezyjne i kartograficzne (Dz. U. Nr 30, poz. 163, z póz. zm.), Language: Polish, English: The Act of 17 May 1989, The Geodetic and Cartographic Law

[18] Ustawa z 18 lipca 2001 roku - Prawo wodne (Dz. U. Nr 115, poz. 1229, z póz. zm.), Language: Polish, English: The Act of 18 July 2001 - The Water Law (Journal of Laws No. 115, item 1,229, as amended)

[19] Ustawa z dnia 13 października 1998 r. - Przepisy wprowadzajace ustawy reformujace administrację publiczna (Dz. U. Nr 133, poz. 872). Language: Polish, English: The provisions introducing the acts reforming public administration (Journal of Laws No. 133, item 872).

[20] Źróbek, R.; Źróbek, S.; Kuryj, J. 2012. Gospodarka nieruchomościami z komentarzem do wybranych procedur. Katowice: Wydawnictwo GALL, ISBN: 978- 83-60968-16-1. Language: Polish, English: Real Estate Management with a commentary for selected procedures. 